\title{
MEAN DIFFERENCES OF TOTAL CHOLESTEROL LEVELS AMONG VEGETARIANS AND NONVEGETARIANS AT MAHA VIHARA MAITREYA DUTA PALEMBANG
}

\author{
Lathifah Nudhar ${ }^{1}$, Subandrate $^{2}$, Susilawati ${ }^{3}$, Liniyanti Oswari ${ }^{2}$ \\ ${ }^{1}$ Undergraduate Medical Student, Faculty of Medicine, Universitas Sriwijaya, Palembang, ${ }^{2}$ Department of \\ Biochemistry, Faculty of Medicine, Universitas Sriwijaya, Palembang, ${ }^{3}$ Department of Clinical Pathology, Faculty \\ of Medicine,Universitas Sriwijaya, Palembang, Indonesia
}

\section{ABSTRACT}

Total cholesterol level is one of the risk factor of cardiovascular disease. The proportion rate of hypercholesterolemia in Indonesia remains high, numbering around one third of (35.9\%) Indonesians. Hypercholesterolemia is a modifiable risk factor, one of early measures that can be taken to prevent hypercholesterolemia is nutritional intervention. A dietary pattern high in plant sources and lower fat consumption has been recommended by several health organisation for prevention of hypercholesterolemia. This study was intended to determine mean difference of cholesterol level between vegetarian and nonvegetarian in Maha Vihara Maitreya Duta Palembang. This was an observational analytical study with cross-sectional design. A total of 173 subjects at Maha Vihara Maitreya Duta Palembang was included which consist of 80 Vegetarian and 93 Nonvegetarian. Measurement of total cholesterol level was done using rapid diagnostic test (RDT) Autocheck $\mathbb{R}$ Multi Monitoring System and parametric Independent T Test was chosen as method of statistical analysis. $p<0.001$ indicates significant differences of total cholesterol level between vegetarian $(172.51 \pm 39.05 \mathrm{mg} / \mathrm{dL})$ and nonvegetarian $(228.67 \pm 68.07$ $\mathrm{mg} / \mathrm{dL}$ ) groups. The mean differences of total cholesterol of vegetarian group is $56,16 \mathrm{mg} / \mathrm{dl}$ lower than non vegetarian groups. A significant differences exist in total cholesterol level between vegetarian and non vegetarian group at Maha Vihara Maitreya Duta Palembang. Vegetarian groups has lower total cholesterol level compared to nonvegetarian.

Keywords: Cholesterol; nonvegetarian; vegetarian

\section{ABSTRAK}

Kadar kolesterol total merupakan salah satu faktor risiko terjadinya penyakit kardiovaskular. Angka kejadian hiperkolesterolemia di Indonesia masih tinggi yaitu sekitar sepertiga (35,9\%) dari total penduduk di Indonesia. Hiperkolesterolemia merupakan suatu faktor risiko yang dapat dicegah, salah satu langkah awal dalam mencegah kondisi hiperkolesterolemia adalah intervensi nutrisi. Pola makan yang menekankan pada konsumsi bahan makanan nabati dan mengurangi asupan lemak telah direkomendasikan beberapa organisasi kesehatan untuk pencegahan hiperkolesterolemia. Penelitian ini bertujuan untuk mengetahui perbedaan rerata kadar kolesterol total antara vegetarian dan nonvegetarian di Maha Vihara Maitreya Duta Palembang. Penelitian ini merupakan penelitian analitik observasional dengan desain studi potong lintang. Terdapat 173 subjek yang merupakan jemaat di Maha Vihara Maitreya Duta Palembang yang terdiri atas 80 vegetarian dan 93 nonvegetarian. Pengukuran kadar kolesterol total dilakukan dengan menggunakan rapid diagnostic test (RDT) Autocheck ${ }^{\circledR}$ Multi Monitoring System dan hasilnya dianalisis menggunakan uji parametrik Independent T Test. Didapatkan nilai $p<0,001$ yang menunjukkan terdapat perbedaan bermakna antara kadar kolesterol total pada kelompok vegetarian $(172,51 \pm 39,05 \mathrm{mg} / \mathrm{dL})$ dan nonvegetarian $(228,67 \pm 68,07 \mathrm{mg} / \mathrm{dL})$. Rerata kadar kolesterol total pada kelompok vegetarian lebih rendah $56,16 \mathrm{mg} / \mathrm{dL}$ dibanding nonvegetarian. Terdapat perbedaan bermakna kadar kolesterol total antara kelompok vegetarian dan nonvegetarian di Maha Vihara Maitreya Duta Palembang. Kelompok vegetarian memiliki kadar kolesterol total lebih rendah dibanding nonvegetarian.

Kata kunci: Kolesterol; nonvegetarian; vegetarian

Correspondence: Subandrate, Department of Biochemistry, Faculty of Medicine, Universitas Sriwijaya, Jl. Dr M. Ali Komp. RSMH km 3,5 Palembang, South Sumatra 30136 Indonesia. E-mail: subandrate@unsri.ac.id

pISSN:2355-8393 • eISSN: 2599-056x • doi:

- Fol Med Indones. 2020;56:197-202 • Received 23 Jan 2019 • Accepted 11 Jul 2019

- Open access under CC-BY-NC-SA license • Available at https://e-journal.unair.ac.id/FMI/ 


\section{INTRODUCTION}

Lipid profiles are one of the risk factors for cardiovascular disease (Ray et al 2014). Verma et al. (2015) stated that an increase in lipid profile and the tendency of dyslipidemia indicated a higher risk for cardiovascular disease. Specifically, in Indonesia, it was found that around one in three people aged $=15$ years had total cholesterol levels above normal values according to NCEP-ATP III. This consisted of a combined population with cholesterol levels in the borderline category $(200-239 \mathrm{mg} / \mathrm{dL})$ and high $(240$ $\mathrm{mg} / \mathrm{dL}$ ) of $35.9 \%$, while others were residents who had low HDL and high LDL levels and were very high with each percentage of $22.9 \%$ and $15.9 \%$ (Riskedas Biomedis 2013). About $22.9 \%$ of the population in Indonesia have low HDL levels and $15.9 \%$ of the population has high and very high LDL levels. Lifestyle changes such as western lifestyle diet, decreased physical activity and sedentary behavior are the main risk factors for dyslipidemia (Qi et al 2015).

Nutrition is believed to be the most important factor in the initial steps to prevent death and disability due to cardiovascular disease (Murray et al 2013). People with vegetarian diet consumes a large portion of plant-based foods and does not consume animal meat have been shown to reduce total cholesterol (Wang et al., 2015). Collaborative analysis of seven studies with a total of 124,706 subjects also showed that mortality of coronary heart disease (CHD) was significantly lower in vegetarians compared to nonvegetarians (Huang et al., 2012). Study on the differences in the mean total cholesterol levels between vegetarians and nonvegetarians is still controversial to date, besides this kind of study has never been conducted in Palembang and the number of vegetarians who are members of the Indonesian Vegetarian Society in Maha Vihara Maitreya Duta Palembang is increasing every year. The purpose of this study is to determine the differences in the mean total cholesterol levels between vegetarian and nonvegetarian groups at the Maha Vihara Maitreya Duta Palembang.

\section{MATERIALS AND METHODS}

The type of this study is an observational analytic study with a cross-sectional study design conducted in August-November 2018 at the Maha Vihara Maitreya Duta Palembang.

The population of this study were all vegetarian and nonvegetarian groups at Maha Vihara Maitreya Duta Palembang, while the minimum number of samples used was 62 subjects in each vegetarian and nonvegetarian group obtained through the hypothesis test formula of two one-sided populations. Sampling was done with consecutive sampling method. This study uses primary data and data collection that collected with direct examination of total cholesterol levels in the blood using the Autocheck ${ }^{\circledR}$ Multi Monitoring System cholesterol test and measurement of height and weight after respondents informed consent and filling out the forms containing personal data include age, gender and diet. The independent variable in this study is diet. The dependent variable in this study is total cholesterol levels. Confounding variables are gender and age.

Data processing and analysis was carried out using Statistical Package for the Social Sciences (SPSS) 25 for Windows. Univariate analysis was carried out to determine the total number and mean value of the variables studied. Bivariate analysis was conducted to test the significance of the differences in the mean of the two groups. Bivariate analysis was performed using an independent $\mathrm{T}$ test. Another analysis was performed using One-way Anova.

\section{RESULTS}

Study with cross-sectional designs has been conducted at the Maitreya Duta Maha Vihara Palembang from September to November 2018 with a total of 173 congregations and has provided a minimum sample size that meets the inclusion and exclusion criteria.

Table 1 shows the gender distribution in vegetarian and nonvegetarian subjects at Maha Vihara Maitreya Duta Palembang, there were 173 subjects, 80 of whom were vegetarians consisting of 31 men and 49 women while 93 others were nonvegetarian consisting of 26 men and 67 women.

Table 2 presents data on the age of the subject of the vegetarian and nonvegetarian groups at the Maha Vihara Maitreya Duta Palembang. Most of the study subjects in the vegetarian group (53.8\%) and nonvegetarian $(46.3 \%)$ were in the age range of $31-40$ years. Table 3 shows the average body mass index between vegetarians and nonvegetarians, The percentage of subjects with a high body mass index in the nonvegetarian group $(32.95 \%)$ was higher than vegetarians $(17.34 \%)$.

The average difference in total cholesterol levels between vegetarians and nonvegetarians is shown in table 4 . The average total cholesterol of the vegetarian group was $172.51 \pm 39.052 \mathrm{mg} / \mathrm{dL}$ and the mean total 
cholesterol of the nonvegetarian group was $228.67 \pm$

$68.069 \mathrm{mg} / \mathrm{dL}$.

Table 1. Distribution of subjects based on gender

\begin{tabular}{cccc}
\hline \multirow{2}{*}{ Gender } & Vegetarian & Nonvegetarian & \multirow{2}{*}{ Total } \\
\cline { 2 - 3 } & $\mathrm{n}(\%)$ & $\mathrm{n}(\%)$ & \\
\hline Male & $31(18)$ & $26(15)$ & 57 \\
Female & $49(28.3)$ & $67(38.7)$ & 116 \\
Total & $80(46.3)$ & $93(53.7)$ & 173 \\
\hline
\end{tabular}

Table 2. Distribution of subjects by age

\begin{tabular}{cccc}
\hline Age & Vegetarian & Nonvegetarian & \multirow{2}{*}{ Total } \\
\cline { 2 - 3 } (in year) & $\mathrm{n}(\%)$ & $\mathrm{n}(\%)$ & 4 \\
$11-20$ & $2(1,2)$ & $2(1.2)$ & 29 \\
$21-30$ & $19(11)$ & $10(5.8)$ & 81 \\
$31-40$ & $43(24.8)$ & $38(22)$ & 39 \\
$41-50$ & $14(8)$ & $25(14.5)$ & 10 \\
$>50$ & $2(1.2)$ & $18(10.4)$ & 173 \\
Total & $80(46)$ & $93(54)$ & \\
\hline
\end{tabular}

Table 3. Distribution of subjects based on body mass index

\begin{tabular}{|c|c|c|c|c|c|c|c|}
\hline \multirow[b]{2}{*}{ Diet } & \multirow[b]{2}{*}{$\mathrm{n}$} & \multicolumn{4}{|c|}{ Body Mass Index } & \multirow[b]{2}{*}{$\begin{array}{c}\text { Mean } \\
\left(\mathrm{kg} / \mathrm{m}^{2}\right)\end{array}$} & \multirow[b]{2}{*}{$\begin{array}{c}\mathrm{p} \\
\text { value* }\end{array}$} \\
\hline & & $\begin{array}{l}\text { High } \\
\text { BMI }\end{array}$ & $\%$ & $\begin{array}{c}\text { Normal } \\
\text { BMI }\end{array}$ & $\%$ & & \\
\hline Nonvegetarian & 93 & 57 & 32.95 & 36 & 19.08 & $24.63 \pm 3.92$ & 004 \\
\hline Vegetarian & 80 & 30 & 17.34 & 50 & 10.98 & $23.58 \pm 3.36$ & 0.04 \\
\hline
\end{tabular}

Table 4. Mean differences of total cholesterol levels amongst vegetarians and nonvegetarians

\begin{tabular}{ccccc}
\hline Total Cholesterol & $\begin{array}{c}\text { Mean } \pm \text { s.d } \\
(\mathrm{mg} / \mathrm{dL})\end{array}$ & $\begin{array}{c}\text { Mean Differences } \\
(\mathrm{mg} / \mathrm{dL})\end{array}$ & IK Value 95\% & p value* \\
\hline Vegetarian & $\begin{array}{c}172.51 \pm 39.05 \\
\text { Nonvegetarian }\end{array}$ & 56,16 & $163.82-181.20$ & 0.001 \\
\hline *Independent T Test, $\mathrm{p}<0.05$ & & & $214.65-242.69$ &
\end{tabular}

The difference in mean cholesterol levels between the two groups showed significant results $(\mathrm{p}<0.001)$ based on the results of the independent $\mathrm{T}$ test.

Table 5. Total cholesterol level differences between vegetarians

\begin{tabular}{|c|c|c|c|c|}
\hline $\begin{array}{l}\text { Vegetarians diet } \\
\text { type }\end{array}$ & $\mathrm{n}$ & $\begin{array}{c}\text { Cholesterol } \\
\text { Level } \\
(\mathrm{mg} / \mathrm{dL}) \\
\end{array}$ & s.b & $\begin{array}{c}\mathrm{p} \\
\text { value* }\end{array}$ \\
\hline Lakto-ovo & 65 & 171.75 & 40.013 & \\
\hline Ovo & 4 & 181.50 & 54.311 & 0.886 \\
\hline Vegan & 11 & 173.73 & 29.645 & \\
\hline
\end{tabular}

*One-way Anova, $\mathrm{p}<0.05$
Table 5 shows the difference in mean total cholesterol levels between vegetarians. The highest average cholesterol was in the ovo vegetarian group with an average cholesterol of $181.50 \mathrm{mg} / \mathrm{dL}$. Based on the results of the average difference test using one way ANOVA, the results of $p>0.05$ showed that there was no significant difference between total cholesterol among vegetarian groups.

\section{DISCUSSION}

The population in this study was 173 Buddhists in Maha Vihara Maitreya Duta Palembang who were divided into 80 vegetarians and 93 nonvegetarian people. Most of the subjects were female as many as 49 people 
$(28.3 \%)$ in the vegetarian group and 67 people $(38.7 \%)$ in the nonvegetarian group, most of the subjects were $31-40$ years old, as many as 43 vegetarian people $(24.8 \%)$ and 38 nonvegetarian people $(22 \%)$. The results of the study are consistent with the study conducted by Gan et al (2018) which revealed that most vegetarians are women, this is because women significantly agree that a vegetarian diet supports animal welfare (Hussar \& Harris 2010), besides that women consume vegetables more often so it is easier to change their diet and men tend to find it difficult to stop consuming meat (Diet Change and Demographic Characteristics of Vegans, Vegetarians, SemiVegetarians, and Omnivores, 2014). Concern about weight and physical appearance can also motivate women to become vegetarian (Gallimore, 2015). The results of the study on the age of vegetarian subjects were in line with a study by Pribis, Pencak \& Grajales in 2010 which suggested that the average age of vegetarian was 32 years. The study also revealed that the younger age group significantly preferred the vegetarian diet because of moral reasons and environmental concerns supported by obedience to religion. In addition to these reasons, the study by Allès et al (2017) revealed that the majority of vegetarian dieters are young people for reasons of income and the price of certain foods. Research by Hartmann and Siegrist (2017) expresses contradictory opinions, that states there is no relationship between sociodemographic characteristics of both age and sex with motivation to reduce animal protein intake and become vegetarian.

The average vegetarian body mass index is lower than nonvegetarian, and the percentage of high BMI in the nonvegetarian group is higher than vegetarian $(10.98 \%$ in vegetarians and $19.08 \%$ in nonvegetarian. This study were the same with study by Clarys et al (2014) which suggests that the percentage of subjects with high BMI $(>25 \mathrm{~kg} / \mathrm{m} 2)$ is owned by nonvegetarian subjects with a percentage of $20.6 \%$ among all groups of eating patterns. Marsh et al (2012) argue that it is very possible that a decrease in body mass index is produced from reduced consumption of certain food components such as saturated fat, cholesterol, animal protein, red meat and increased consumption of healthy dietary components, including fruit, vegetables, whole grains, besides, differences in macronutrient intake also influence differences in BMI between vegetarians and nonvegetarian and it is known that high protein and low fiber intake are strongly associated with an increase in IMT.

Vegetarian groups have a total cholesterol level of $172.51 \pm 39.05 \mathrm{mg} / \mathrm{dL}$ with a range of $109-268 \mathrm{mg} / \mathrm{dL}$ and nonvegetarian groups having a mean total cholesterol level of $228.67 \pm 68.07 \mathrm{mg} / \mathrm{dL}$ with a range of $106-384 \mathrm{mg} / \mathrm{dL}$. The results of the analysis using an independent $\mathrm{T}$ test showed a significant difference in total cholesterol between vegetarian and nonvegetarian groups. The results of this study are in accordance with the study by Peni (2014) who conducted a study of differences in total cholesterol levels in members of the Indonesian Vegetarian Society (IVS) and the Maha Vihara Maitreya congregation in Deli Serdang. In the study, there is a significant difference between vegetarian and nonvegetarian cholesterol. These results indicate the benefits of a vegetarian diet that reduces or eliminates consumption of certain foods such as saturated fatty acids, cholesterol, animal protein, animal meat and increases the consumption of plant foods such as fruits, vegetables, whole grains and nuts (Marsh et al 2012). Vegetarian diets have a tendency to be low in saturated fatty acids (SFA) and rich in polyunsaturated fatty acids (PUFAs) which are known to have good effects on fat metabolism (McEvoy et al 2012). Vinagre et al (2014) also suggested that the substitution of SFA with PUFA and MUFA would reduce LDL cholesterol levels through a mechanism to increase the expression of LDL receptors in liver cells and take leftover cholesterol by the liver. In a study by Vinagre et al (2014) there were significant differences between Fraction Clearance Rate (FCR) cholesterol ester emulsions for vegetarians and nonvegetarians. In the subject of vegetarians, FCR cholesterol esters are five times higher than nonvegetarian, this indicates that the residual clearance of plasma kilomycron in vegetarians is more effective than nonvegetarian. The results of the study contradict the study of Lee et al., (2016) which states that there are no significant differences in total cholesterol levels between vegetarians and nonvegetarians, this is due to consumption of some food items that are still allowed in certain vegetarian groups such as vegetarian lacto ovo and ovo consuming eggs, while egg yolks are known to be one of the foods that are high in cholesterol, besides milk and milk products also contribute to the intake of saturated fatty acids and cholesterol (Vinagre et al 2014).

The results of the one-way anova parametric analysis showed that there were no significant differences in total cholesterol levels between the three groups of vegetarians, namely vegetarian lakto-ovo, ovo and vegan at Maha Vihara Maitreya Duta Palembang, indicating that there was no influence on certain vegetarian dietary levels total cholesterol. The study by Jian et al. (2015) proved the same thing, that there were no significant differences between the vegetarian diet group but the study by Ashwini (2016) suggested the opposite, namely there were significant differences in the mean total cholesterol levels between pure vegetarian groups, lakto-ovo vegetarians and ovo 
vegetarian. Differences in cholesterol levels between vegetarian groups in the study can be caused by several factors not measured in this study such as lifestyle, physical activity, dietary patterns and other comorbidities that can influence the results of this study (Huang et al., 2014). In addition, some studies did not find a relationship between dietary differences and a decrease in total cholesterol levels. In the study it is stated that even certain vegetarian groups consumed less fat in their diets, but different rates of cholesterol synthesis could occur in each diet, for example vegetarian lakto-ovo, this diet group absorbed cholesterol 44\% lower but synthesized cholesterol 22\% higher than the vegetarian group, the same thing happened in the vegan group, this group absorbed cholesterol $90 \%$ lower than nonvegetarian but synthesized $35 \%$ more cholesterol (Lütjohann et al 2018).

\section{CONCLUSION}

Based on the results of the study that has been conducted on the Buddhist congregation at the Maha Vihara Maitreya Duta Palembang, it can be concluded that there is a significant difference between the total cholesterol in vegetarian and nonvegetarian groups, the total cholesterol levels of the vegetarian group are lower than nonvegetarian.

\section{REFERENCES}

Allès B, Baudry J, Méjean C, et al (2017). Comparison of sociodemographic and nutritional characteristics between self-reported vegetarians, vegans, and meateaters from the Nutrinet-Sante study. Nutrients 9,1023 .

Ashwini(2016). A Comparative Study of Metabolic Profile, Anthropometric Parameters among Vegetarians and Non-vegetarians- do vegetarian diet have a cardioprotective role? International Journal of Research in Medical Sciences 4

Clarys P, Deliens T, Huybrechts I, et al (2014). Comparison of nutritional quality of the vegan, vegetarian, semi-vegetarian, pesco-vegetarian and omnivorous diet. Nutrients 6,1327

Gallimore T (2015). Understanding the reasons for and barriers to becoming vegetarian in prospective vegetarians and vegans- A qualitative phenomenological exploration, (Doctoral dissertation, MSc Thesis, QC: McGill University).

Gan WY, Boo S, Seik MY, et al (2018). Comparing the nutritional status of vegetarians and non-vegetarians from a Buddhist Organisation in Kuala Lumpur,
Malaysia. Nutritional Status, Dietary Intake and Body Composition 24, 89

Hartmann C, Siegrist M (2017). Consumer perception and behaviour regarding sustainable protein consumption: A systematic review. Trends in Food Science \& Technology 61, 11-25

Huang T, Yang B, Zheng J, et al (2012). Cardiovascular disease mortality and cancer incidence in vegetarians: a meta-analysis and systematic review. Annals of nutrition and metabolism 60, 234-237

Huang YW, Jian ZH, Chang HC, et al (2014). Vegan diet and blood lipid profiles: a cross-sectional study of pre and postmenopausal women. BMC Women's Health 14, 55

Humane League Labs (2014) United States: Diet Change and Demographic Characteristics of Vegans, Vegetarians, Semi-Vegetarians, and Omnivores, available from http://www.humaneleaguelabs.org/static/reports/2014/ 04/diet-change-and-demographic-characteristics1.pdf. Accessed November 12, 2018

Hussar KM, Harris PL (2010). Children who choose not to eat meat: A study of early moral decision-making. Social Development 19, 627-631

Ministry of Health, Republic of Indonesia (2013). Laporan Riset Kesehatan Dasar (Riskesdas) 2013 Bidang Biomedis.Jakarta: Badan Penelitiandan Pengembangan Kesehatan, p 259-260.

Jian ZH, Chiang YC, Lung CC, et al (2015). Vegetarian diet and cholesterol and TAG levels by gender. Public health nutrition 18, 721-726

Lee YJ, Wang MY, Lin MC, et al (2016). Associations between vitamin B-12 status and oxidative stress and inflammation in diabetic vegetarians and omnivores. Nutrients 8,118

Lütjohann D, Meyer S, von Bergmann K, et al (2018). Cholesterol absorption and synthesis in vegetarians and omnivores. Molecular nutrition \& food research 62,1-2

Marsh K, Zeuschner C, Saunders A (2012). Health implications of a vegetarian diet: A review. American Journal of Lifestyle Medicine 6, 250-267

McEvoy CT, Temple N, Woodside JV (2012). Vegetarian diets, low-meat diets and health: a review. Public health nutrition 15, 2287-2294

Murray CJL, Abraham J, Ali MK, et al (2013). The state of US health, 1990-2010: burden of diseases, injuries, and risk factors. Jama 310, 591-606

Peni KL (2014). Perbedaan pola makan, kadar gula darah, kolesterol dan asam urat antara kelompok vegetarian dan non vegetarian di perumahan Cemara Asri Kecamatan Percut Sei Tuan Deli Serdang. Undergraduate thesis on Public Health Science, p 6776 
Pribis P, Pencak RC, Grajales T (2010). Beliefs and attitudes toward vegetarian lifestyle across generations. Nutrients 2, 523-531

Qi L, Ding X, Tang W, et al (2015). Prevalence and risk factors associated with dyslipidemia in Chongqing, China. International journal of environmental research and public health 12, 13455-13458

Ray KK, Kastelein JJP, Matthijs BS, et al (2014). The ACC/AHA 2013 guideline on the treatment of blood cholesterol to reduce atherosclerotic cardiovascular disease risk in adults: the good the bad and the uncertain: a comparison with ESC/EAS guidelines for the management of dyslipidaemias 2011. European heart journal 35, 960-968
Verma M, Verma P, Parveen S, et al (2015). Comparative study of lipid profile levels in vegetarian and non-vegetarian person. Int J Life Sci Sci. Res 1, 89-93

Vinagre JC, Vinagre CCG, Pozzi FS, et al (2014). Plasma kinetics of chylomicron-like emulsion and lipid transfers to high-density lipoprotein (HDL) in lacto-ovo vegetarian and in omnivorous subjects. European journal of nutrition 53, 981-987

Wang F, Zheng J, Yang B, et al (2015). Effects of Vegetarian Diets on Blood Lipids: A Systematic Review and Meta-Analysis of Randomized Controlled Trials. Journal of the American Heart Association: Cardiovascular and Cerebrovascular Disease 4 